\title{
ОСОБЫЕ ОСНОВАНИЯ ОСВОБОЖДЕНИЯ ОТ АДМИНИСТРАТИВНОЙ ОТВЕТСТВЕННОСТИ ЗА НАРУШЕНИЕ ПРАВ ИНТЕЛЛЕКТУАЛЬНОЙ СОБСТВЕННОСТИ
}

\begin{abstract}
Аннотация. Административная ответственность за нарушение прав интеллектуальной собственности устанавливается ст. 7.12 и ст. 14.10 Кодекса Российской Федерации об административных правонарушениях и является одним из способов защиты прав на объекты интеллектуальной собственности. Предметом рассмотрения данной статьи является возможность освобождения от административной ответственности за совершение указанных правонарушений, а также исследование вопроса о необходимости введения дополнительных оснований для освобождения от административной ответственности за нарушение прав интеллектуальной собственности. При написании работы применялся метод анализа, аналогии, моделирования, изучения нормативно-правовых норм и правоприменительной практики. В предлагаемой статье делается вывод о необходимости внесения изменений в статьи 7.12 и 14.10 Кодекса Российской Федерации об административных правонарушениях с целью установления особых оснований освобождения от административной ответственности за указанные правонарушения в связи с возмещением ущерба и примирением с потерпевшим.

Ключевые слова: особые основания, административное правонарушение, патентные права, авторские права, право интеллектуальной собственности, примирение с потерпевшим, освобождение от ответственности, Административная ответственность, административное законодательство, имущественный ушерб.

Review. Administrative liability for intellectual property rights violation is established in the articles 7.12 and 14.10 of the Code of Administrative Offences of the Russian Federation; it is one of the ways to protect intellectual property rights. The subject of the article is the possibility of exemption of administrative liability for such offences, and the study of the problem of the need for introduction of additional reasons for condonation in such cases. The author uses the methods of analysis, analogy, modeling; the research is also based on the study of legal regulations and law-enforcement practice. The author concludes that it is necessary to amend the articles 7.12 and 14.10 of the Code of Administrative Offences of the Russian Federation with special reasons for exemption of administrative liability for the violation of intellectual property rights in case of indemnification and reconciliation with an aggrieved party.

Keywords: administrative legislation, administrative liability, exemption of liability, reconciliation with aggrieved party, intellectual property right, author's rights, patent rights, administrative offence, special reasons, property damage.
\end{abstract}

O бщая часть кодекса Российской Федерации об административных правонарушениях устанавливает несколько оснований освобождения от административной ответственности. Статья 2.9 КоАП РФ «освобождение от административной ответственности в связи с малозначительностью правонарушения», является одним из таких оснований, что признают большинство авторов. Некоторые исследователей исходят из того, что основания освобождения от административной ответственности перечислены в ст. 24.5 КоАП РФ. Среди них: отсутствие события административного правонарушения, отсутствие состава административного правонарушения, действия лица в состоянии крайней необходимо- сти, издания акта амнистии, если такой акт устраняет применение административного наказания, отмена закона, установившего административную ответственность, истечение сроков давности привлечения к административной ответственности, наличие по одному и тому же факту совершения противоправных действий (бездействия) лицом, в отношении которого ведется производство по делу об административном правонарушении, постановления о назначении административного наказания, либо постановления о прекращении производства по делу об административном правонарушении, предусмотренном той же статьей или той же частью статьи настоящего Кодекса или закона субъекта Российской Федерации, либо по- 
становления о возбуждении уголовного дела. Также от ответственности могут быть освобождены собственники транспортных средств и земельных участков, в случае фиксации административного правонарушения средствами автоматической фото- видеофиксации, при определенных условиях. Относительно отдельных оснований освобождения от административной ответственности в юридической науке существуют разногласия. Так, например, Чаннов С.Е рассматривает следующие основания освобождения от административной ответственности: «крайняя необходимость, невменяемость, издание акта амнистии, истечение срока давности, наличие постановления о наложении административного наказания либо постановления о прекращении производства по делу об административном правонарушении, либо постановления о возбуждении уголовного дела, несовершеннолетие правонарушителя и малозначительность деяния» [1].

По нашему мнению, отсутствие события административного правонарушения и отсутствие состава административного правонарушения не является основанием освобождения от административной ответственности, в данном случае отсутствует само административное правонарушение, а, следовательно, административная ответственность не может наступать. Аналогичная ситуация складывается и в отношении невменяемости лица, совершившего правонарушение. Обязательным признаком административного правонарушения является виновность: «Административным правонарушением признается противоправное, виновное действие (бездействие) физического или юридического лица...» [2, ч.1 ст. 2.1]. В случае невменяемости деликвента, отсутствует виновность, поэтому отсутствует административное правонарушение, а, следовательно, административная ответственность не может наступать. Однако не все авторы придерживаются данной точки зрения [3]. Ко всем вышеперечисленным обстоятельствам можно применить термин «общие» поскольку они могут быть применены к большинству административных правонарушений.

Отдельного внимания заслуживает ч.9 ст. 24.5 КоАП РФ: «иные предусмотренные настоящим Кодексом обстоятельства, при наличии которых лицо, совершившее действия (бездействие), содержащие признаки состава административного правонарушения, освобождается от административной ответственности» [4, п.2 ч.1 ст.11]. Дан- ное положение было введено в связи с принятием Федерального закона от 08.06.2015 № 140-Ф3 «0 добровольном декларировании физическими лицами активов и счетов (вкладов) в банках и о внесении изменений в отдельные законодательные акты Российской Федерации». Следует отметить, что особые основания освобождения от административной были в КоАП и до принятия Федерального закона № 140, а именно: примечания к статьям $6.8,6.9,6.16 .1,14.32,15.11$ КоАП РФ. Указанным законом введены основания освобождения от административной ответственности за правонарушения, предусмотренные статьями 14.1, 19.15.1, 19.15.2 КоАП РФ.

К данным основаниям можно применить термин «особые». Подробнее рассмотрим некоторые из них. Как отмечается, разница между приведенными основаниями заключается в том, что: «Общие основания освобождения от административной ответственности базируются на анализе и учете характера правонарушения и личности правонарушителя; частные - на анализе и учете обстоятельств, характеризующих постпротивоправное поведение лица» [5, С. 64]. Так, примечание к статье 6.8 КоАП РФ устанавливает возможность освобождения от административной ответственности: «Лицо, добровольно сдавшее приобретенные без цели сбыта наркотические средства, психотропные вещества, их аналоги или растения, содержащие наркотические средства или психотропные вещества, либо их части, содержащие наркотические средства или психотропные вещества, освобождается от административной ответственности за данное административное правонарушение». Данное положение носит социально-ориентированный характер и направлено на недопущение потребления наркотических средств лицом, приобрётшим такие средства, а также на стимулирование передачи наркотических средств органам государственной власти. Как верно отмечает И.П. Долгих: «отечественные юристы всерьез озадачились поиском мер, применение которых к лицам, совершившим административные правонарушения, было бы более действенным, нежели назначение последним заслуженного, но не всегда эффективного наказания» [6]. Такие меры могут иметь и экономический характер, например, в случаях, установленных Федеральным законом № 140 [4].

Важным упущением действующего законодательства об административных правонарушениях, на наш взгляд, является отсутствие такого 
основания освобождения от административной ответственности, как примирение с потерпевшим, ведь добровольное возмещение ущерба, нанесенного административным правонарушением, будет иметь позитивный экономический эффект, в отличии от привлечения лица к административной ответственности. Состоятельность предложения о возможности освобождения от административной ответственности доказывает наличие такого основания в качестве освобождения от ответственности в Уголовном кодексе Российской Федерации [7, ст. 76].

Публичная ответственность за нарушение прав интеллектуальной собственности является специфичной в силу сложности самого объекта гражданского правоотношения [8, ст. 1227]. В связи с этим, в науке высказываются мнения о необходимости изменения подхода к публичной ответственности за нарушение авторских прав: «при этом стоит отметить, что нарушение авторских прав относится к области частного права, и такие дела, по нашему мнению, должны быть отнесены к делам частно-публичного обвинения, однако, как и большинство преступлений, они относятся к уголовным делам публичного обвинения» [9]. Закономерным видится возможность освобождения от административной ответственности за данные правонарушения.

Ст. 7.12 и ст. 14.10 КоАП РФ, устанавливающие ответственность за нарушение прав интеллектуальной собственности, лишены особых оснований освобождения от административной ответственности. Как не раз отмечалось, интеллектуальна собственность занимает важные места в экономике развитых стран [10, С. 4]. Этим обуславливается необходимость обеспечения приоритета введения в легальный оборот результатов интеллектуальной деятельности перед публичной ответственностью за нарушение прав на такие результаты. Одним из действенных механизмов, позволяющих добиться поставленной цели, может явится институт освобождения от административной ответственности, а именно: освобождение от административной ответственности в связи с примирением сторон. Поскольку такое основание отсутствует в общей части КоАП РФ, статьи 7.12 и 14.10 необходимо дополнить примечанием, согласно которому лицо, допустившее указанное административное правонарушение освобождается от административной ответственности при условии возмещения причиненного ущерба и примирения с потерпевшей стороной.
На практике реализовать данное предложение возможно следующим образом: при выявлении административного правонарушения нарушителю сообщают сведения о правообладателе, затем нарушитель предпринимает меры по взаимодействию с правообладателем и выяснению условий возмещения причиненного вреда. Поскольку рассмотрение дел об административных правонарушениях, предусмотренных статьями 7.12 и 14.10 КоАП РФ отнесено к компетенции суда [2, ст. 23.1], после составления протокола об административном правонарушении до рассмотрения дела по существу, деликвент будет иметь возможность возместить ущерб, причиненный правообладателю. В случае, если нарушитель и правообладатель достигли консенсуса относительно возмещения причиненного вреда, правообладатель в судебном заседании подает заявление (ходатайство), в котором просит прекратить дело об административном правонарушении в отношении деликвента. На основании данного заявления и руководствуясь ч. 9 ст. 24.5 КоАП РФ суд прекращает производство по делу об административном правонарушении.

Следует отметить, что Кодекс Российской Федерации об административных правонарушения предусматривает возможность решения вопроса о возмещении имущественного ущерба, в случае отсутствия спора, однако, как правило, суд отказывает в удовлетворении данных требований, разъясняя право потерпевшего обратится в суд в порядке гражданского судопроизводства [11] или же вопрос о возмещении вреда на ставится вовсе [12].

Внесение предложенных изменений позволит нарушителю не только возместить ущерб за незаконное использование результата интеллектуальной детальности, но и, получить право на использование результат интеллектуальной деятельности на законных основаниях, в договорном порядке. Правообладатель, реализуя свой имущественный интерес, будет избавлен от необходимости обращения в суд в порядке гражданского судопроизводства, а также, от несения судебных издержек, поскольку ущерб возмещается в добровольном порядке, что является одним из обстоятельств при которых, нарушитель освобождается от административной ответственности. Данные действия ретроспективно легализуют незаконный оборот результатов интеллектуальной деятельности, что будет иметь положительный экономический эффект. 


\section{Библиография:}

1. Чаннов С.Е. Основания для освобождения от административной ответственности // Гражданин и право. 2011. № 4. C. 3-14.

2. Кодекс Российской Федерации об административных правонарушениях от 30.12 .2001 № 195 -Ф3 (ред. от 29.06.2015) // СЗ РФ. 2002. № 1 (ч.1). Ст. 1.

3. Орлов И.В. Невменяемость как освобождение от административной ответственности // Юрист. 2003. № 1.С. 23-26.

4. Федеральный закон от 08.06.2015 № 140-Ф3 "0 добровольном декларировании физическими лицами активов и счетов (вкладов) в банках и о внесении изменений в отдельные законодательные акты Российской Федерации"

5. Жданов Н.М., Жданова А.Н. Освобождение от административной ответственности // Административное право и процесс. 2012. № 4. С. 61-65.

6. Долгих И.П. Быть или не быть институту освобождения от административной ответственности в Российской Федерации? // Юридические исследования. - 2015.-№ 1.-C.1-15. DOI: 10.7256/2409-7136.2015.1.13775.

7. Уголовный кодекс Российской Федерации от 13.06.1996 № 63-Ф3 (ред. от 08.06.2015) // С3 РФ. 1996. № 25. Ст. 2954.

8. Гражданский кодекс Российской Федерации (часть четвертая) от 18.12.2006 № 230-Ф3 (ред. от 31.12.2014) // СЗ РФ. 2006. № 52 (1 ч.). Ст. 5496.

9. Стулов С.А. Правовой режим охраны и защиты авторских прав на программное обеспечение для ЭВМ // Информационное право. 2010. № 3. С. 20-23.

10. Войниканис Е.А. Право интеллектуальной собственности в цифровую эпоху: парадигма баланса и гибкости. М.: Юриспруденция. 2013. 552 с.

11. Решение Советского районного суда г. Орел по делу № 5-136/2013 от 25.06.2013 г.

12. Решение Вязниковского городского суда Владимирской области по делу №5-37-2011 от 08.07.2011 г.

13. О. В. Маркова Перспективы правовой защиты интеллектуальной собственности и способы укрепления устойчивого элемента системы правовой защиты интеллектуальной собственности // Политика и 0бщество.-2012.-6.C. 101-106.

\section{References (transliterated):}

1. Channov S.E. Osnovaniya dlya osvobozhdeniya ot administrativnoi otvetstvennosti // Grazhdanin i pravo. 2011 . № 4. S. 3-14.

2. Kodeks Rossiiskoi Federatsii ob administrativnykh pravonarusheniyakh ot 30.12.2001 № 195-FZ (red. ot 29.06.2015) // SZ RF. 2002. № 1 (ch.1). St. 1.

3. Orlov I.V. Nevmenyaemost' kak osvobozhdenie ot administrativnoi otvetstvennosti // Yurist. 2003. № 1.S. 23-26.

4. Federal'nyi zakon ot 08.06.2015 № 140-FZ "O dobrovol'nom deklarirovanii fizicheskimi litsami aktivov i schetov (vkladov) v bankakh i o vnesenii izmenenii v otdel'nye zakonodatel'nye akty Rossiiskoi Federatsii"

5. Zhdanov N.M., Zhdanova A.N. Osvobozhdenie ot administrativnoi otvetstvennosti // Administrativnoe pravo i protsess. 2012. № 4. S. 61-65.

6. Dolgikh I.P. Byt' ili ne byt' institutu osvobozhdeniya ot administrativnoi otvetstvennosti v Rossiiskoi Federatsii? // Yuridicheskie issledovaniya. - 2015.-№ 1.-S.1-15. DOI: 10.7256/2409-7136.2015.1.13775.

7. Ugolovnyi kodeks Rossiiskoi Federatsii ot 13.06.1996 № 63-FZ (red. ot 08.06.2015) // SZ RF. 1996. № 25. St. 2954.

8. Grazhdanskii kodeks Rossiiskoi Federatsii (chast' chetvertaya) ot 18.12.2006 № 230-FZ (red. ot 31.12.2014) // SZ RF. 2006. № 52 (1 ch.). St. 5496.

9. Stulov S.A. Pravovoi rezhim okhrany i zashchity avtorskikh prav na programmnoe obespechenie dlya EVM // Informatsionnoe pravo. 2010. № 3. S. 20-23.

10. Voinikanis E.A.Pravo intellektual'noi sobstvennosti vtsifrovuyu epokhu: paradigma balansai gibkosti. M.: Yurisprudentsiya. 2013. $552 \mathrm{~s}$.

11. Reshenie Sovetskogo raionnogo suda g. Orel po delu № 5-136/2013 ot 25.06 .2013 g.

12. Reshenie Vyaznikovskogo gorodskogo suda Vladimirskoi oblasti po delu №5-37-2011 ot 08.07.2011 g.

13. O. V. Markova Perspektivy pravovoi zashchity intellektual'noi sobstvennosti i sposoby ukrepleniya ustoichivogo elementa sistemy pravovoi zashchity intellektual'noi sobstvennosti // Politika i Obshchestvo.-2012.-6.-C. 101-106. 